\title{
Abnormalities in the regulation of variable region genes that encode for antibodies to DNA may be a central factor in the pathogenesis of systemic lupus erythematosus
}

\author{
A K Singh
}

\begin{abstract}
Systemic lupus erythematosus (lupus) is characterised by the excessive and spontaneous production of antibodies to DNA. In animal models of lupus, and in humans, antibodies to DNA have been directly implicated in pathogenesis. The variable region genes that encode for reactivity of antibodies to DNA have, in general, not been regarded as a risk factor in lupus. Recent evidence from several workers, including ourselves, does not sustain this dogma. Individual autoreactive $\mathrm{V}$ genes appear to be repeatedly used and to have an affinity for DNA. These genes are present in subjects with the disease and in some, but not all, normal subjects. Presumably, in some subjects carrying autoreactive $V$ genes in their germline, these genes are normally silenced by regulatory factors, including cytokines, and in others with disease there is a breakdown in regulation. Experimental evidence suggests that multiple cytokines may have a role and that this role is complex.
\end{abstract}

(Ann Rheum Dis 1993; 52: 378-383)

Systemic lupus erythematosus (lupus) is an autoimmune disease that is characterised by the presence of antibodies to DNA, which have been correlated with disease activity. In animal models of lupus, antibodies to DNA have been shown to transfer disease to normal mice with the formation of immune deposits in the kidney. ${ }^{1-4}$ Moreover, immunoglobulin eluted from the glomeruli of patients and mice with disease are enriched for reactivity to DNA, of higher avidity for dsDNA than the antibodies to DNA in serum samples of the same subjects. ${ }^{56}$ Not all antibodies to DNA are nephritogenic. Two groups of antibodies to DNA can be distinguished: 'natural' autoantibodies and 'pathogenic' autoantibodies. Natural autoantibodies are by definition not associated with disease and can be detected in normal subjects at low titres. Further, they are IgM in isotype, anionic or neutral in charge, and in the case of murine Ig, when injected into normal animals do not deposit in the kidney. In contrast, 'pathogenic' autoantibodies are present in high titres in subjects with lupus, are IgG in isotype, fix complement well, are cationic, and in mice are required by definition to deposit in the kidney of normal animals. The origins of either natural or nephritogenic antibodies to DNA are as yet unknown. Various properties of antibodies to DNA have been correlated with nephritogenicity. These include cationic charge, isotype, complement fixation, avidity, and idiotype. Collectively, these properties have suggested that the antigen binding region may influence nephritogenicity. Nonetheless, the variable region genes ( $V$ genes) that encode antibodies to DNA have not been regarded as a risk factor in lupus. ${ }^{78}$ This is because the $\mathrm{V}$ genes encoding for antibodies to DNA are nearly identical with their counterparts encoding for exogenous antigens, and because the RFLP pattern on Southern blot analysis is the same for autoimmune subjects as it is for normal subjects. ${ }^{9-14}$ Therefore, despite the prediction that multiple genetic loci probably affect the aetiology of lupus, the immunoglobulin gene complex in subjects with lupus is thought by many workers to be essentially normal.

A hypothesis that is currently favoured proposes that $\mathrm{V}$ genes encoding for antibodies to DNA may be present in the general population but are expressed in low levels and are intrinsically non-autoreactive. In subjects with lupus, however, a polyclonal B cell activation and an autoantigen driven immune stimulation results in the overexpression of these $\mathrm{V}$ genes causing the spontaneous production of antibodies to DNA and other self reactive antibodies. ${ }^{15} 16$ This hypothesis does not, however, sufficiently take into consideration the powerful evidence from studies of twins $\mathrm{s}^{17}$ and observations from inbred murine lupus models for the critical role of genetic factors in lupus. Nor does this hypothesis adequately account for the multiple cytokine abnormalities that have been documented. In this regard, an alternative hypothesis needs to be considered. ${ }^{18} 19$ The simultaneous inheritance of background genes and some sets of individual autoreactive germline $\mathrm{V}$ genes that are repeatedly used to encode for antibodies to DNA could result in an increased risk for disease. It is conceivable that differences in the germline immunoglobulin 
gene repertoire might, in circumstances of abnormal immunoregulation from one or multiple cytokine defects, as part of a polyclonal B cell response, result in the expression of structurally different autoantibodies in normal and autoimmune subjects. These autoantibodies could mimic self structures that further select for autoantibody producing clones $^{20}$ or these autoantibodies could themselves be pathogenic, or both. The purpose of this paper is to examine the hypothesis that cytokine regulatory factors may be a central factor that contributes to the breakdown in tolerance that occurs in lupus.

\section{Murine lupus as a model for the human disease}

Inbred murine models of lupus have provided an invaluable insight into the human disease. There are many similarities between murine and human lupus. In both, antibodies to DNA correlate with disease activity and can be eluted from nephritic kidneys. Furthermore, the pattern of organ disease also appears to be similar: in both, arthritis, nephritis, and vasculitis are common clinicopathological abnormalities. The overwhelming advantage of using animal models is their ease of manipulation and the knowledge of their genetic origins (reviewed by Theofilopoulos and Dixon $^{21}$ ). Over the last two decades, three main types of lupus mice have been used. The MRL/pr-lpr mice, which are of known genetic derivation (LG $75 \%, \mathrm{AKR} 12.6 \%, \mathrm{C} 3 \mathrm{H}$ $12 \cdot 1 \%$, and C57BL $60.3 \%$ ), the New Zealand mice which are of unknown derivation, and the BXSB mice (from C57BL/6 and SB/Le). In all these mice, the genetic background predisposes to a late life disease that becomes clinically manifest and then fatal in the second year of life. Additionally, an accelerating factor, for instance the lpr gene in MRL mice, when acting on the lupus prone genetic background, causes conversion to an early life disease clinically apparent in the first few months of life and fatal within 5-7 months.

\section{Certain $V_{H}$ genes may be intrinsically autoreactive}

By taking advantage of the opportunities presented by hybridoma technology, many variable region genes that encode reactivity to a variety of antigens and haptens have been cloned and sequenced in murine models of lupus and in humans. By comparing these sequences, several subgroups of anti-DNA $V_{H}$ genes have been reported (table). One of the largest murine $\mathrm{V}_{\mathrm{H}}$ gene subgroups contains the $\mathrm{H} 102$ and $\mathrm{H} 241 \mathrm{~V}_{\mathrm{H}}$ gene. These two $\mathrm{V}_{\mathrm{H}}$ genes encode two IgG antibodies to DNA derived from MRL/lpr-lpr lupus mice (Gangemi R M $\mathrm{R}$, Singh A K, et al, unpublished data). ${ }^{22}$ Nine other $\mathrm{V}_{\mathrm{H}}$ genes have also been reported. These include $\mathrm{B} / \mathrm{W} 16, \mathrm{C} 72$, A52, $16-19,{ }^{23} \mathrm{H} 45-5,{ }^{24}$ $\mathrm{H} 8, \mathrm{H} 238, \mathrm{H} 161,{ }^{25}$ and $10 \mathrm{~B} 10 \mathrm{~S} .{ }^{26}$ With the exception of $10 \mathrm{~B} 10 \mathrm{~S}$, they all encode antibodies to DNA and are all derived from lupus mice. The nucleotide sequence of BXW16 represents the germline configuration because of the pattern of differences seen when all the sequences in this subset are compared with each other. ${ }^{27}$ We have also studied the expression of the $V_{H} 102 / 241$ gene in a large panel of hybridomas developed by Foster et al from MRL/lpr-lpr lupus mice. ${ }^{28}$ Specific CDR oligonucleotide probes complementary to the H102/241 $V_{H}$ gene were used in high stringency northern blot analysis and show that the H102/241 $V_{H}$ gene may be used by another three of 14 antibodies to DNA tested. $^{29}$ Jang and Stollar, ${ }^{30}$ using ultraviolet crosslinking of helical oligonucleotides, have shown that the $\mathrm{H} 241 \mathrm{~V}_{\mathrm{H}}$ gene selectively binds DNA. Taken together, these results provide compelling evidence that this subgroup of $\mathrm{V}_{\mathrm{H}}$ genes may have an intrinsic affinity for DNA.

Other subgroups have also been identified. The $\mathrm{H} 130 \mathrm{~V}_{\mathrm{H}}$ gene defines a subset that is a part of the $\mathrm{J} 558 \mathrm{~V}_{\mathrm{H}}$ gene family: A6 $1,{ }^{31}$ PME $77,{ }^{27}$ and $\mathrm{H} 438^{32}$ are all co-members of this subgroup (table). Interestingly, the $\mathrm{H} 130 \mathrm{~V}_{\mathrm{H}}$ gene is highly homologous to $\mathrm{H} 18$, a germline gene, from the normal BALB/c mouse strain. ${ }^{33}$ $\mathrm{H} 18$ is not expressed in $\mathrm{BALB} / \mathrm{c}$ mice, however, perhaps because it is downregulated in the BALB/c background. Other groups have also documented the repetitive use of variable region genes in antibodies to DNA and also in antibodies to histone. ${ }^{34-39}$

In human lupus there has been great difficulty in immortalising $B$ cells reactive to IgG antibodies to DNA. Many studies have been published on IgM autoantibodies which may represent the natural autoantibody

Comparison of eight monoclonal antibodies to DNA that use the same $V_{H}$ gene (the germline gene is termed MRL 330 and has been cloned by us; data not shown). This subgroup of expressed $V_{H}$ genes to encode for antibodies to DNA suggests that this $V_{H}$ gene may be intrinsically autoreactive. Abbreviations. $m A b$, monoclonal antibody; glom dep, glomerular immune deposition; $V_{H}$ gene $N, V_{H}$ gene nucleotide differences with $B X W 16 ; V_{H}$ gene $A A, V_{H}$ gene amino acid differences with BXW16. ND=not done.

\begin{tabular}{|c|c|c|c|c|c|c|c|c|c|c|}
\hline$m A b$ & Strain & Isotype & Antigen & Glom dep & $V_{H} N$ & $V_{H} A A$ & D Gene & fH Gene & VK Family & $f K$ Gene \\
\hline $\begin{array}{l}\text { BXW16 } \\
82-3 \\
\text { H102 } \\
\text { H241 }\end{array}$ & $\begin{array}{l}\text { NZB/W } \\
\text { MRL } \\
\text { MRL } \\
\text { MRL }\end{array}$ & $\begin{array}{l}\text { IgMK } \\
\text { IgMK } \\
\text { IgGK } \\
\text { IgGK }\end{array}$ & $\begin{array}{l}\text { ssDNA } \\
\text { ssDNA } \\
\text { ssDNA } \\
\text { ss } \\
\text { dsDNA }\end{array}$ & $\begin{array}{l}\text { ND } \\
\text { ND } \\
\text { No } \\
\text { Yes }\end{array}$ & $\begin{array}{l}- \\
1 \\
3\end{array}$ & $\begin{array}{l}- \\
1 \\
1\end{array}$ & $\begin{array}{l}\text { FL16 } 1 \\
\text { SP2 } 3 / 5 / 6 / 7 / 8 \\
\text { SP2 } 2 / c S P 2 \cdot 2 / 3 / 6 \\
\text { Q52 }\end{array}$ & $\begin{array}{l}2 \\
4 \\
2 \\
3\end{array}$ & $\begin{array}{r}9 \\
5 \\
20 \\
21\end{array}$ & $\begin{array}{l}2 \\
4 \\
2 \\
4\end{array}$ \\
\hline $\begin{array}{l}\text { BV16-19 } \\
\text { A52 }\end{array}$ & $\begin{array}{l}\mathrm{NZB} / \mathrm{W} \\
\mathrm{BZB} / \mathrm{W}\end{array}$ & $\begin{array}{l}\text { IgGK } \\
\text { IgGK }\end{array}$ & $\begin{array}{l}\text { ssDNA } \\
\text { ssDNA } \\
\text { dsDNA }\end{array}$ & $\begin{array}{l}\text { ND } \\
\text { Yes }\end{array}$ & $\begin{array}{l}3 \\
4-43\end{array}$ & $\begin{array}{l}2 \\
2\end{array}$ & $\begin{array}{l}\text { FL16.2/SP2.3 } \\
\text { SP2 } 3\end{array}$ & $\begin{array}{l}3 \\
2\end{array}$ & $\begin{array}{l}1 \mathrm{~A} \\
8\end{array}$ & $\begin{array}{l}4 \\
1\end{array}$ \\
\hline C72 & $\mathrm{NZB} / \mathrm{W}$ & IgGK & $\begin{array}{l}\text { ssDNA } \\
\text { dsDNA }\end{array}$ & ND & $3-18$ & $3-8$ & $\mathrm{Q} 52 / \mathrm{FL} 16 \cdot 2 / \mathrm{cSP} 2 \cdot 3$ & 4 & 19 & 5 \\
\hline $45-5$ & MRL & IgGK & DNA & ND & $4-10$ & $3-5$ & $\mathrm{SP} 2 \cdot 3 / 2 \cdot 6$ & 3 & 4 & 2 \\
\hline
\end{tabular}


population. Thus information derived from IgM antibodies to DNA may be of limited value in understanding the aetiology of autoimmune disease. Winkler et al have presented sequence data on $\mathrm{V}$ genes encoding human IgG anti-DNA hybridomas which have a specificity that fits the criteria for pathogenicity discussed here. ${ }^{40}$ Their data on six monoclonal IgG antibodies to DNA are similar to information from murine studies: human antibodies to DNA show evidence of somatic mutation which appears to be driven by antigens. Their data suggest that DNA is the antigen and is in agreement with murine data from other workers. ${ }^{35}$ Interestingly, two of the six IgG antibodies to DNA use $V_{H}$ genes which encode for natural IgM antibodies. The simplest interpretation of these observations is that at least some of the pathogenic antibodies to DNA might be derived from the natural autoantibody repertoire by somatic mutation.

The grouping of these expressed $V_{H}$ genes into subgroups suggests that individual germline genes may themselves be autoreactive. Although the notion of 'autoimmune specific' genes is not new, the overwhelming consensus that specific lupus encoding genes are not present in the immune repertoire is supported by several lines of experimental evidence, including the many examples of variable region gene segments that are identical to germline genes from normal subjects (reviewed by Barrett ${ }^{41}$ ). More appealing, however, is the belief that autoreactive genes may be present in lupus and some, but not all, normal subjects and that these genes are downregulated in the normal subjects and upregulated under certain circumstances in subjects with the disease. Speculatively, this view could explain the observation that family members of patients with lupus may have antibodies to DNA in their serum at low levels but never develop the disease. Conceivably, these relatives may lack background genes, cytokine defects, or other as yet unidentified factors that downregulate autoreactive B cells so that low levels of IgM autoantibody are produced with the effect that clinical disease is mitigated.

\section{Autoreactivity may be encoded for in the germline}

The concept that single autoreactive genes may be present in the germline of some normal and autoimmune subjects at an increased risk of developing lupus has not been examined, until recently, in any great detail. In the past, the use of coding region probes hampered the detection of single variable region genes in the repertoire because these large probes invariably hybridised to all members of a particular $\mathrm{V}_{\mathrm{H}}$ gene family. For J558, the largest murine $\mathrm{V}_{\mathrm{H}}$ gene family, this meant that scores of bands were seen on Southern blot analysis. It was therefore difficult to detect the presence of a particular autoreactive gene in the repertoire.

More recently, however, the use of oligonucleotide probes complementary to the unique hypervariable part (CDR) of the variable gene has made it possible to detect individual genes in the germline. ${ }^{42}$ The technique requires the sequential use of a pair of oligonucleotide probes under high stringency conditions that detect homologous genes which differ by only one base pair. In contrast with coding region probes, these shorter oligoprobes detect unique regions of an immunoglobulin gene and therefore only a few bands, representing one or more genes, are seen on Southern blot analysis. By combining data from two oligoprobes it is then possible to detect an individual gene in the germline repertoire. In this way, oligonucleotide probes complementary to the CDR1 and CDR2 regions of the $\mathrm{V}_{\mathrm{H}}$ gene of $\mathrm{H102/241}$ have been hybridised to Southern blots containing germline DNA from various autoimmune and normal strains of mice. ${ }^{14}{ }^{15}$ It has been observed that the $V_{H} 102 / 241$ gene was present in all strains, including two normal strains, of the IgH ' $j$ ' haplotype (of MRL) but was absent in most other normal strains. In a similar analysis with oligonucleotide probes from the $\mathrm{V}_{\mathrm{H}} 564$ gene, Ghatak et al found that the preserved germline allele (approx $5.2 \mathrm{~kb}$ in size) was present in one normal parental strain (SWR) but was absent in the other parent (NZB) and in the normal C57BL/6 mice. ${ }^{43}$ Taken together, these results suggest that a gene encoding for an antibody to DNA is present in some normal and autoimmune subjects with the same immunoglobulin gene haplotype but not in others.

The mere presence of a gene in the germline does not neccesarily mean that it will be transcribed. Autoreactive genes that encode for antibodies to DNA may be present in some normal subjects who, under physiological conditions, remain unstimulated or suppressed. Their high level of expression in lupus could then result from the abnormal response of $\mathrm{B}$ cells to normal cytokine regulatory stimuli or from an appropriate $B$ cell response to abnormal levels of certain cytokines. Either could produce the striking polyclonal B cell activation that occurs before the clinical expression of disease.

An alternative possibility is that cytokines activate a distinct $\mathrm{B}$ cell lineage that may be expanded or hyperresponsive in subjects with lupus. In this regard, in NZB hybrid mice there is an early activation of the CD5+Ly-1 B cell subset which produces IgM ('natural') autoantibodies in response to lipopolysaccharide (LPS) stimulation. The $\mathrm{V}_{\mathrm{H}}$ repertoire of these Ly-1 B cells appears restricted ${ }^{44}$ and conserved $\mathrm{V}_{\mathrm{H}}$ genes appear to be used. Whether pathogenic autoantibodies originate from these 'natural' autoantibodies is unclear. The human counterpart to the Ly-1 B cell is the Leu-1 B cell which produces IgM antibodies to DNA, rheumatoid factor, and antibodies to tetanus. ${ }^{45} 46$ The pathophysiological significance of the Ly-1 (or Leu-1) subset is unclear, especially as the Ly-1 B cell population is not expanded in the other murine lupus prone strains and the proliferation of Ly-1 B cells does not appear to correlate with the production of antibodies to DNA. ${ }^{47} 48$ 
Cytokines may be central to the pathogenetic defect in lupus

The notion that regulatory factors may be important is suggested chiefly by three sets of observations. The first is based on elegant work by Klinman and coworkers. ${ }^{49-52}$ Their observations that splenic B cells from mice with lupus compared with normal mice are polyclonally activated early (in younger mice) and that this activation precedes and predicts the development of autoimmune disease suggests that autoantibody production is initiated by polyclonal activation, possibly from $\mathrm{T}$ cell or macrophage derived factor(s). The second piece of evidence is based on experiments by Weigert's group ${ }^{53}$ and by Goodnow and coworkers, ${ }^{54}{ }^{55}$ who have shown that autoreactive B cells are not clonally deleted but are functionally and reversibly silenced or anergised. The third piece of data comes from the use of interleukin 2 (IL-2) treatment to ameliorate disease in $\mathrm{MRL} / \mathrm{lpr}-\mathrm{lpr}$ mice. ${ }^{56}$ Mice treated with IL-2 developed milder nephritis and arthritis than control mice. Moreover, IL-2 treatment was associated with a decrement in immunoglobulin production. Thus collectively there is a substantive body of experimental evidence that suggests a potentially important pathophysiological role for cytokine regulation of autoreactive B cells in lupus.

Most workers have so far focused their attention on IL-2, IL-1, and tumour necrosis factor $\alpha(\mathrm{TNF} \alpha)$. Studies of IL-2 have examined levels in lupus mice and the administration of IL-2 in vivo. Levels of IL-2 in autoimmune mice (NZB hybrids, MRL/prlpr, and BXSB) show an age related decline which correlates with disease activity. ${ }^{57}$ At 6 weeks of age IL-2 activity in lupus prone mice appears comparable with normal C57/BL6 mice; after 12 weeks of age, however, there is a striking decrease in IL-2 levels. Although experiments that have used IL-2 gene treatment in MRL/pr-lpr mice support a role for IL-2 in the autoimmune process, ${ }^{55}$ not all studies concur. Kelley et $a l^{58}$ have shown that an IL-2 receptor antibody administered to $\mathrm{NZB} / \mathrm{W}$ lupus mice results in significant amelioration of disease activity, whereas Owen et al found that IL-2 treatment caused neither an improvement nor an acceleration of disease activity. ${ }^{59}$

The role of IL-1 and TNF in the pathogenesis of lupus has been studied by several groups in detail; however, again there is no agreement. Both Kelley's ${ }^{60}{ }^{61}$ and Beller's ${ }^{62} 63$ group have studied IL-1 and TNF expression in macrophages. Kelley and coworkers found enhanced TNF $\alpha$ and IL-1 expression in glomerular macrophages from $M R L / p r$ mice, whereas Beller's group found defective IL-1 and normal TNF $\alpha$ gene expression in peritoneal macrophages in several autoimmune murine strains. In contrast, Jacob and $\mathrm{McD}$ evitt have found low levels of $\mathrm{TNF} \alpha$ in peritoneal macrophages of NZW mice and have shown that treatment with $\mathrm{TNF} \alpha$ delayed the development of autoimmunity in NZB hybrid mice. ${ }^{64}$ The basis for the TNF $\alpha$ deficiency appears to be a polymorphism in the $5^{\prime}$ regulatory region of the TNF $\alpha$ gene in NZW mice. ${ }^{65}$ Even so, the role of TNF $\alpha$ in disease in these mice with lupus appears controversial; Jacob has offered an explanation for this conflict. ${ }^{66} \mathrm{He}$ suggests that the measurement of TNF $\alpha$ expression in the kidney (by Kelley and coworkers) may have little relevance to the systemic disease because immune complexes deposited in the kidney could trigger the increased expression of TNF $\alpha$ and IL-1 $\beta$ in macrophages resident or recruited to the kidney and therefore account for the local upregulation of these cytokines. Interestingly, because $\mathrm{TNF} \alpha$ physiologically stimulates the release of IL-2 from Th $1 \mathrm{~T}$ cells the deficiency in TNF $\alpha$ may explain the age related decrease in IL-2 levels. ${ }^{67}$

The in vivo role of TNF $\alpha$ and IL-1 is important from a disease perspective and has been studied. Brennan et al injected TNF $\alpha$ or IL- $1 \alpha$ into NZB/W lupus or $\mathrm{C} 3 \mathrm{H} / \mathrm{HeJ}$ control mice at low and high doses over an interval of several months. ${ }^{67}$ Administration of the lower dose of each cytokine $(0.2 \mu \mathrm{g})$ accelerated kidney disease and shortened survival, whereas at the higher dose $(2.0 \mu \mathrm{g})$ there was no effect on renal disease or survival. In this study, however, it is impossible to separate out the effect of the administered cytokine directly on $B$ cells as opposed to their effect on $T$ cells (with concomitant release of IL-4 and IL-6). Nonetheless, a role for IL- 1 and TNF $\alpha$ or another cytokine in an in vivo setting is suggested. Other cytokine defects involving IL-6, IL-4, and B cell differentiating factor have been proposed but the evidence is weak and conflicting. ${ }^{68-70}$

The evidence for a direct effect on B cells by cytokines in subjects with lupus is restricted to in vitro experiments. Klinman has studied the production of IgG1 and IgG2a by autoimmune spleen B cells from NZB/W and MRL/lpr-lpr mice treated in vitro by IL-4 and interferon $\gamma .^{51}$ A spot enzyme linked immunosorbent assay (ELISA) was used for the measurement of $\mathrm{Ig}$ producing cells and the isotypic and subclass specificity of the secreted immunoglobulin. ${ }^{71}$ It is worth noting that spot ELISA has the advantage that it can separate out the effect of a cytokine in inducing $B$ cell proliferation from the effect of the cytokine in enhancing Ig production. Thus the assay is at once sensitive and specific. Klinman observed that NZB/W B cells incubated with IL-4 plus LPS have a defect in their ability to undergo class switching and to proliferate after switching. In MRL/lprlpr mice, however, Klinman found that the response to IL-4 plus LPS was similar to controls but that the age related change in isotype from IgM to IgG in $\mathrm{MRL} / \mathrm{lpr}$-lpr mice was the result of increased production of interferon $\gamma$. We have preliminary data with IL4 and interferon $\gamma$, in an identical protocol to Klinman, that is in agreement (Lebedeva $\mathrm{T}$ and Singh A K, unpublished data). Jandl et al have presented data that suggests an in vitro hyperresponsiveness of human lupus B cells to IL-1 and have correlated their in vitro findings with disease activity. ${ }^{72}$ Other workers have 
also found that there may be defects in the responsiveness of $\mathrm{B}$ cells to normal levels of cytokines. ${ }^{73}$ Indeed, at 6 weeks of age, activated and resting $B$ cells from MRL-lpr/lpr mice are hyperresponsive to LPS stimulation compared with $\mathrm{C} 3 \mathrm{H} / \mathrm{HeJ}$ and $\mathrm{C} 57 \mathrm{BL} / 6$ mice (Lebedeva $\mathrm{T}$ and Singh A $\mathrm{K}$, unpublished data; also ref 74) suggesting that in addition to any abnormality in cytokine levels there is an intrinsic defect in the B cells.

The studies with IL-2, IL-1, TNF $\alpha$, IL-4, and interferon $\gamma$ suggest that multiple cytokine defects are characteristic of the immune response in mice with lupus. Abnormal levels of other cytokines have also been reported. ${ }^{75} 76$ Given the clearly myriad interactions of different cytokines, it is conceivable that the abnormal production of one or two cytokines may initiate the release of a cascade of other cytokines that amplify the effect of the initiating stimulus; abnormal levels of several cytokines involved in this cascade could then be an epiphenomenon. Collectively, the current experimental observations point to a complex and yet incompletely defined role for cytokines in lupus. It is possible that a cytokine regulatory defect early in the disease results in polyclonal B cell activation of either normal or hyperresponsive B cells with an associated upregulation of intrinsically autoreactive $\mathrm{V}$ genes. Subsequently, an autoantigen directed immune response could perpetuate the autoimmune injury, increasing the affinity of the autoantibody for the antigen. In this regard, Pucetti $e t a l^{20}$ have shown that an Ig light chain can induce autoantibodies in a normal mouse and have proposed that the autoantigen in lupus may actually be an idiotype that is released as part of the early polyclonal B cell response and which could in turn select out autoreactive $B$ cell clones.

Ultimately, it is necessary to examine the cytokine regulation of individual autoreactive $\mathrm{V}$ genes to determine the specific contribution of cytokines to the pathogenesis of lupus. This work is presently underway in our laboratory. ${ }^{77}$ The formal testing of the hypothesis proposed in this paper should provide invaluable insights into the processes that occur early in the autoimmune response and which may in fact be involved in its initiation. Although conclusions drawn from animal studies need to be interpreted cautiously with regard to human disease, it is likely that many of the immunological and molecular defects that result in the breakdown in tolerance to self in mice with lupus will be similar in humans.

1 Madaio M P, Carlson J, Cataldo J, Ucci A, Migliorini P, Pankewycz O G. Murine monoclonal anti-DNA antibodies bind directly to glomerular antigens and form immune deposits. F Immunol 1987; 138: 2883-9.

2 Ebling F M, Hahn B H. Restricted subpopulations of DNA antibodies in kidneys of mice with systemic lupus: comparison of antibodies in serum and renal eluates. Arthritis Rheum 1980; 23: 392-403.

3 Vlahakos D V, Foster M H, Adams S, et al. Monoclona anti-DNA antibodies derived from lupus-prone mice form immune deposits at distinct glomerular location form immune deposits at distinct glomerular location and induce different structural and functional

4 Raz E, Brezis M, Rosenmann E, Eilat D. Anti-DNA anti- bodies bind directly to renal antigens and induce kidney dysfunction in the isolated perfused rat kidney. F Immunol 1989; 142: 3076-82.

5 Pankewycz O G, Migliorini P, Madaio M P. Polyreactive autoantibodies are nephritogenic in murine lupus nephritis. F Immunol 1987; 139: 3287.

6 Saskai T, Hatakeyama A, Shibata S, et al. Heterogeneity of immune-complex derived anti-DNA antibodies associated with lupus nephritis. Kidney Int 1991; 39: 746-53.

7 Kofler R, Dixon F J, Theofilopolous A N. The genetic origin of autoantibodies. Immunol Today 1987; 8: 374-80.

8 Theofilopoulos A N, Kofler R, Singer P A, Dixon F J. Molecular genetics of murine lupus models. Adv Immunol 1989; 146: 61-109.

9 Koffler R, Noonan D J, Levy D E, et al. Genetic elements used for a murine lupus anti-DNA autoantibody are closely related to those for antibodies to exogenous antigens. F Exp Med 1985; 161: 805-15.

10 Dersimonian H, McAdam K P W J, Mackworth-Young C, Stollar B D. The recurrent expression of variable region segments in human IgM anti-DNA autoantibodies. segments in human IgM antimol 1989; 142: 4027-33.

11 Cairns E, Kwong P C, Misener V, Peter I P, Bell D A Siminovitch K A. Analysis of variable region genes encoding a human anti-DNA antibody of normal origin. f Immunol 1989; 143: 685-91

12 Koffler R, Perlmutter D J, Noonan D J, Dixon F J, Theofilopolous A N. Ig heavy chain variable region gene complex of lupus mice exhibits normal restriction fragment length polymorphism. $f$ Exp Med 1985; 162: 346-51.

13 Koffler R, Strohal R, Balderas E M, et al. Immunoglobulin $\mathrm{k}$ light chain variable region gene complex organization and Ig genes encoding anti-DNA antibodies in lupus and Ig genes encoding anti-DNA
mice. $\mathcal{C}$ Clin Invest 1988; 82: 852-9.

14 Trepicchio Jr W, Barrett K J. The Igh-V locus of MRL mice: restriction fragment length polymorphism in eleven strains of mice as determined with $\mathrm{VH}$ and $\mathrm{D}$ gene probes. f Immunol 1985; 134: 2734-9.

15 Theofilopoulos A N, Dixon F J. Etiopathogenesis of murine systemic lupus erythematosus. Immunol Rev 1981; 55: $179-216$.

16 Arnett F C, Reveille J D, Wilson R W, Provost $T$ T Bias W B. Systemic lupus erythematosus: current state of the genetic hypothesis. Semin Arthritis Rheum 1984; 14: the gen $24-35$.

17 Block S R, Winfield J B, Lochshin M D, Dangelo W A, Christian C L. Studies of twins with systemic lupus erythematosus: a review of the literature and presentation of 12 additional sets. $A m \mathcal{F} M e d 1975 ; 59: 533$.

18 Singh A K. What is the role of cytokines in the excessive production of autoantibodies in systemic lupus ery-
thematosus? $f R$ Coll Physicians London 1992; 26: 374-6.

19 Pascual V, Widhopf G, Capra J D. The human VH repertoire: a restricted set of $\mathrm{VH}$ genes may be the target
of immune regulation. Int Rev Immunol 1992; 8: 147-57.

20 Pucetti A, Koizumi T, Migliorini P, Andre-Schwartz J Barrett H J, Schwartz R S. An immunoglobulin light chain from a lupus-prone mouse induces autoantibodies in normal mice. f Exp Med 1990; 171: 1919-30.

21 Theofilopoulos A N, Dixon F J. Murine models of systemic lupus erythematosus. Adv Immunol 1985; 37: 269-390.

22 Singh A K, Gangemi R M R, Barrett K J, Structural and genetic determinants of immune deposition in lupus nephritis. Fournal of the American Society of Nephrology 1990; 1: 540.

23 Eilat $\mathrm{D}$. The role of germline gene expression and somatic mutation in the generation of autoantibodies to DNA. Mol Immunol 1990; 27: 203-10.

24 Forster I, Hua G, Rajewsky K. Germline antibody V regions as determinants of clonal persistence and malignan growth in the B cell compartment. EMBO $f 1988 ; 7$ 3693-703

25 Bailey N C, Fidanza V, Mayer R, Mazza G, Fougereau M, Bona $C$. Activation of clones producing selfreactive antibodies by foreign antigen and antiidiotype antibody carrying the internal image of the antigen. $\mathcal{f}$ Clin Invest 1989; 84: 744-56.

26 Chua M M, Goodgal S H, Karush F. Germline affinity and germline variable region genes in the $\mathrm{B}$ cell response. germline variable region gene

27 Eilat D, Fischel R. Recurrent utilization of genetic elements in $\mathrm{V}$ regions of anti-nucleic acid antibodies from autoin V regions of anti-nucleic acid antibodies
immune mice. $\mathcal{F}$ Immunol 1991; 147: 361-8.

28 Foster M H, MacDonald M, Barrett K J, Madaio M P. VH gene analysis of spontaneously activated $B$ cells in adult MRL-lpr/pr mice. J 558 bias is not limited to classic lupus autoantibodies. F Immunol 1991; 147: 1504-11.

29 Singh A K, Foster M, Gangemi R M R, Madaio M P Barrett KJ. The potentially nephritogenic H102/241 VH gene may be overexpressed in MRU/pr-lpr lupus mice. fournal of the American Society of Nephrology 1991; 2: 563.

30 Jang Y J, Stollar B D. Ultraviolet cross-linking of helical oligonucleotides to two monoclonal MRL-lpr/pr antiDNA autoantibodies: variations in $\mathrm{H}$ and $\mathrm{L}$ binding to DNA. F Immunol 1990; 145: 3353-9.

31 Tsao B P, Ebling F M, Roman C, Panosian-Sahakian N, Calame K, Hahn B H. Structural characteristics of the variable regions of immunoglobulin genes encoding a vathogenic antibody in murine lupus mice. $f$ Clin Invest 1990; 85: 530-40.

32 Foster $M$ H, Madaio M P, Barrett $K \mathrm{~J}$. Variable region sequence analysis of anti-DNA antibodies: evidence for a lupus autoantibodies. DNA Cell Biol 1992; 11: 175-81. 
33 Trepicchio Jr W, Maruya A, Barrett K J. The heavy chain genes of a lupus anti-DNA autoantibody are encoded in the germline of a nonautoimmune mouse strain and conserved in mice polymorphic for this gene locus. f Immunol 1987; 139: 3139-45.

34 Komisar J L, Leung K Y, Crawley R R, Talal N, Teale J M. Ig VH gene family repertoire of plasma cells derived from lupus prone MRL/pr and MRU ++ mice. $f$ Immunol 1990; 143: 340-7.

35 Shlomchik $M$, Mascelli $M$, Shan $H$, et al. Anti-DNA antibodies from autoimmune mice arise by clonal expansion and somatic mutation. 7 Exp Med 1990; 171: 265-92.

36 O'Keefe T L, Bandyopadhyay S, Datta S K, ImanshiKari $T$. $V$ region sequences of an idiotypically connected family of pathogenic anti-DNA autoantibodies. $\mathcal{F}$ Immunol 1990; 144: 4275-83.

37 Marion T N, Tillman D M, Jou N T. Interclonal and intraclonal diversity among anti-DNA antibodies from and (NZBXNZW)F1 mouse. F Immunol 1990; 145 2322-32.

38 Jacob L, Tron F. Monoclonal anti-deoxyribonucleic antibodies. I. Isotype and specificity studies. F Immunol 1982, 128: 895-8.

39 Monestier M. Variable region genes of anti-histone autoantibodies from a MRL $/ \mathrm{Mp}$-lpr/lpr mouse. Eur 7 Immunol antibodies from a $M$

40 Winkler T H, Fehr H, Kalden J R. Analysis of immunoglobulin variable region genes from human IgG anti-DNA hybridomas. Eur f Immunol 1992; 22: 1719-28.

41 Barrett K J. Anti-DNA antibodies, autoimmunity and the immunoglobulin repertoire. Int Rev Immunol 1989; 4, 43-78.

42 Guillaume T, Rubinstien D B, Young F, et al. Individual VH genes detected with oligonucleotide probes from the complementary-determining regions. I Immunol 1990, 145: $1934-45$.

43 Ghatak S, O'Keefe T L, Imanshi-Kari T, Datta S K. Selective strain distribution of a germline $\mathrm{VH}$ gene for pathogenic anti-DNA autoantibody family. Int Immuno 1990; 2: 1003-12.

44 Tarlinton D, Stall A M, Herzenberg L A. Repetitive usag of immunoglobulin $\mathrm{VH}$ and $\mathrm{D}$ gene segments in CD5 Ly-1 B clones of (NZBXNZW) F1 mice. EMBO 71988 7: 3705-10.

45 Hardy $R$ R, Hayakawa $K$, Shimizu M, Yamasaki $K$ Kishimoto $\mathrm{T}$. Rheumatoid factor secretion from human Leu-1 + B cells. Science 1986; 236: 81-3.

46 Casali $P$, Burastero S E, Nakamura $M$, Inghirami G Notkins A L. Human lymphocytes making rheumatoid fotkins A L. Human lymphocytes making rheumatoid factor and antibody to SS DNA
subset. Science 1987; 236: 77-81.

47 Manohar V, Brown E, Leirson W M, Chused T M. Expression of Lyt-1 by a subset of B lymphocytes. f Immunol 1982; 129: 532-8.

48 Wofsky D, Chiang N Y. Proliferation of Ly-1 B cells in autoimmune NZB and (NZBXNZW)F1 mice. Eur $\mathcal{F}$ Immunol 1987; 17: 809-14.

49 Klinman D M, Steinberg A D. Systemic autoimmune disease arises from polyclonal $\mathrm{B}$ cell activation. $\mathcal{F} \operatorname{Exp} \mathrm{Med}$ disease arises from polyc

50 Klinman D M, Eisenberg R A, Steinberg A D. Developmen of the autoimmune B cell repertoire in MRL/pr-lpr mice. f Immunol 1990; 144: 506-12.

51 Klinman D M. Regulation of B cell activation in autoimmune mice. Clin Immunol Immunopathol 1989; 53, S25-35.

52 Klinman D M. Polyclonal B cell activation of lupusprone mice precedes and predicts the developmen of autoimmune disease. $f$ Clin Invest 1990; 86: 1249-54.

53 Erikson J, Radic M Z, Camper S A, Hardy R R, Carmack C Weigert $M$. Expression of anti-DNA immunoglobulin transgenes in non-autoimmune mice. Nature 1991; 349, transge

54 Adams E, Basten A, Goodnow C C. Intrinsic B-cell hyporesponsiveness accounts for self-tolerance in lysozyme/anti-lysozyme double transgenic mice. Proc Nat Acad Sci USA 1990; 87: 5687-91.

55 Goodnow C, Crosbie J, Adelstien S, et al. Altered immunoglobulin expression and functional silencing of self- reactive B lymphocytes in transgenic mice. Nature 1988 334: $676-82$.

56 Gutierrez-Ramos J C, Andreu J L, Revilla Y, Vinuela E, Martinez-A C. Recovery from autoimmunity of MRL/pr mice after infection with an interleukin-2/vaccinia recombinant virus. Nature 1990; 346: 271-4.

57 Dauphinee M J, Kipper S B, Wofsky D, Talal N. Interleukin deficiency is a common feature of autoimmune mice. f Immunol 1981; 127: 2483-7.

58 Kelley VE, Gaulton G E, Hattori M, Ikegami H, Eisenbarth G, Strom T B. Anti-interleukin 2 receptor antibody suppresses murine diabetic insulitis and lupus nephritis. Immunol 1988; 140: 59-61.

59 Owen K I, Shibata T, Izui S, Walker S E. Recombinan interleukin-2 therapy of systemic lupus erythematosus in the New Zealand black/New Zealand white mouse. $\mathcal{F}$ Bio Response Mod 1989; 8: 366-74.

60 Boswell J M, Yui M A, Endres S, Burt D W, Kelley V E. Novel and enhanced IL-1 gene expression in autoimmune mice with lupus. F Immunol 1988; 141: 118-24.

61 Boswell J M, Yui M A, Burt D W, Kelley V E. Increased tumor necrosis factor and IL-1 beta gene expression in the kidneys of mice with lupus nephritis. F Immunol 1988; 141: 3050-4.

62 Levine J, Hartwell D, Beller D I. Imbalanced cytokine production by macrophages from autoimmune-prone mice. Immunol Lett 1991; 30: 183-92.

63 Donnelly R P, Levine J, Hartwell D Q, Frendl G, Fentin $M \mathrm{~J}$, Beller D I. Aberrant regulation of IL-1 expression in macrophages from young autoimmune mice. $\mathcal{F}$ Immunol 1990; 145: 3231-9.

$64 \mathrm{Jacob}$ C O, McDevitt H O. Tumor necrosis factor $\alpha$ in murine autoimmune 'lupus' nephritis. Nature 1988; 331 $356-8$

65 Jongeneel C V, Acha-Orbea H, Blankenstien T. A polymorphic minisatellite in the tumor necrosis factor a promoter identifies an allele unique to the NZW mouse strain. 7 Exp Med 1990; 171: 2141-6.

$66 \mathrm{Jacob}$ C O. Tumor necrosis factor $\alpha$ in autoimmunity: pretty girl or old witch? Immunol Today 1992; 13: 122-5.

67 Brennan D C, Yui M A, Wuthrich R P, Kelley V E. Tumo necrosis factor and IL-1 in New Zealand black/white mice. F Immunol 1989; 143: 3470-5.

68 Linker-Israeli $M$, Deans R. Dysregulated lymphokine production in systemic lupus erythematosus. Ann NY Acad Sci 1989; 577: 567

69 Pelton B K, Speckmaier M, Hylton W, Farrant J, Denman A M. Cytokine-independent progression of immunoglobulin production in vitro by B lymphocytes from gatients with systemic lupus erythematosus. Clin Exp patients with systemic lupu

70 Hirose T, Hara M, Kitani A, et al. Abnormal production of and response to $B$ cell growth factor and $B$ cell differentiation factor in patient with systemic lupus erythematosus. Scand f Immunol 1985; 21: 141-50.

71 Klinman D M, Steinberg A D. Novel ELISA spot assays to quantitate $\mathrm{B}$ cells specific for $\mathrm{T}$ cells and bromelated red blood cell autoantigens. F Immunol Methods 1987; 102: 157-64.

72 Jandl R C, George J L, Dinarello C A, Schur P H. The effect of interleukin 1 on IgG synthesis in systemic lupus erythematosus. Clin Immunol Immunopathol 1987; 45: 384-94.

73 Umland S P, Go N F, Cupp J E, Howard M. Responses of $\mathrm{B}$ cells from autoimmune mice to IL-5. $\mathcal{f}$ Immunol 1989; 142: 1528-35.

74 Cavallo T, Granholm N A. Lipopolysaccharide from gramnegative bacteria enhances polyclonal $B$ cell activation and exacerbates nephritis in MRL/pr mice. Clin Exp Immunol 1990; 82: 515-21.

75 Lampe M A, Patarca $R$, Iregui M V, Cantor $H$. Polyclonal $B$ cell activation by Eta-1 cytokine and the development of systemic autoimmune disease. 7 Immunol 1991; 147: of systemic

76 Herron L R, Coffman R L, Bond M W, Kotzin B L Increased autoantibody production by NZB/NZW B cells in response to IL-5. F Immunol 1988; 141: 842-8.

77 Singh A K. IL-4 causes up-regulation of an autoreactive Vh gene that frequently encodes for anti-DNA antibodies in lupus mice [abstract]. Fournal of the American Society of Nephrology 1992; 3: 615 . 